\title{
Islamophobia in Australia: From Far-Right Deplorables to Respectable Liberals
}

\author{
Scott Poynting * and Linda Briskman \\ School of Social Sciences and Psychology, Western Sydney University, Penrith NSW 2751, Australia; \\ 1.briskman@westernsydney.edu.au \\ * Correspondence: s.poynting@wessternsydney.edu.au; Tel.: +61-2-9852-5222
}

Received: 13 September 2018; Accepted: 27 October 2018; Published: 30 October 2018

\begin{abstract}
In Australia since about the turn of the millennium, discrimination against Muslims has been increasingly normalized, made respectable, and presented as prudent precaution against violent extremism. Vilification of Muslims has posed as defending 'Australian values' against those who will not integrate. Liberal political leaders and press leader-writers who formerly espoused cultural pluralism now routinely hold up as inimical the Muslim folk devil by whose otherness the boundaries of acceptability of the national culture may be marked out and policed. The Muslim Other is positioned not only as culturally incommensurate, but dangerously so: dishonest, criminally inclined, violent, misogynist, homophobic, backward, uncivilized. On the far right, extremist nationalist organizations incite racist hatred under cover of this rhetoric, often cloaked as reasonable common sense. This paper undertakes an ideology analysis of political and media discussion, and examines the forms of social control that they advance and sustain.
\end{abstract}

Keywords: Islamophobia; extremism; right wing; western values; clash of civilizations

\section{Introduction}

In July 2018 the Murdoch broadsheet, The Australian, reported on an address given by Australia's Citizenship Minister, Alan Tudge, in what was described as 'a landmark speech to a closed meeting of the Australia/UK Leadership Forum in London' (Benson 2018, p. 1; Tudge 2018). Among the stereotyped themes in his speech was a call for Australia to mount a 'muscular' defense of western liberal values, and an amplification of the values clash narrative, using examples popular with 'the right' such as the prospect of female genital cutting $(\mathrm{FCG})^{1}$, child marriage, and domestic violence. He warned that Australia was veering toward a separatist multicultural model.

In many ways, this large front-page spread, in a newspaper whose target group is an educated elite, is unremarkable, given the 'values' rhetoric emerging from the federal government and the Murdoch media onslaught against Muslims. This previously included a 2015 campaign described as 'an open-minded but unflinching series of articles analysing Muslim Australia' (The Australian 2015). Much of the content comprised sophisticated, well-written pieces that were nevertheless little different from the views of extreme right-wing groups.

However, what this current article reveals is emblematic of the manner in which an anti-Muslim partnership between government and media is now firmly in place and undisguised. Islamophobia is now thoroughly globalized in the west, and the exploitation by The Australian instances well the

1 We use the term FGC as opposed to the commonly used term of 'Female Genital Mutilation', as the term 'cutting' avoids the value judgments in the designation 'mutilation'. Further, both terms refer to a considerable range of procedures, with the term 'mutilation' objected to by many who have undergone some of these procedures. 
interchanges between right-wing xenophobia, Islamophobia, and nationalism in the Australian context. Racism in Australia is booming (Grattan 2018; Wilson 2018).

We argue here that there is a significant ideological and political relationship between extreme right-wing groups and politicians and media outlets that would claim liberal respectability. What was previously identified as the 'creeping blight' of Islamophobia in Australia (Briskman 2015) is now institutionalized and taken for granted, endangering democratic principles, cultural pluralism, and indeed the rule of law.

\section{Theorizing Transition from Deplorables to Respectables}

The literature on Islamophobia is voluminous and increasing. In this paper, we incorporate some of this corpus, but our objective is to trace some key changes in the political and moral discourses in Australia concerning Muslims that has emerged since around 2001. We illustrate how certain ideological elements of Islamophobia have become hegemonic over that period and are now entrenched in 'common sense'.

We draw here on Antonio Gramsci's theory of hegemony, as most completely, though fragmentarily, expressed in his famous Prison Notebooks (Gramsci 1971). Hegemony is the cultural-political dominance of leading ('directive') fractions of the ruling class, in which consent is secured from the masses, albeit reinforced by 'the armor of coercion' and secured through control of the 'apparatuses of hegemony' including the media, schools, and the courts. In building and maintaining such hegemony, the work of intellectuals (broadly defined) is crucial. They secure intellectual and moral leadership for the ruling class fractions by generalizing their interests, through articulating them to the contradictory lived experiences of the subaltern strata. Gramsci's concept of 'common sense' (Gramsci 1971, pp. 134, 197, 199, 323-33, 348, 396, 419-25, 444) is crucial in this process. This is 'common' in that it is shared; it is the everyday, taken-for-granted assumptions about the world, the inherited commonplaces and conventional wisdom, and so on, common to the mass of ordinary people-rather like folklore. It is the philosophy of the 'man-in-the-mass'. It is 'the conception of the world which is uncritically absorbed from the various social environments in which the moral individuality of the average man is developed' (Gramsci 1971, p. 419). It is 'fragmentary' and 'incoherent' in congruence with the social and cultural position of the masses whose philosophy it is (Gramsci 1971, p. 419). Intellectuals organic to the ruling class take up elements of this common sense, render them more authoritative and coherent as a worldview, and propagate them in this form to the 'masses', thus adhering them to the agendas of the leading class fractions, as if these were in accord with their own interests. This framework applies usefully here, since we argue that right-wing intellectuals have worked to entrench ideological elements of Islamophobia as everyday and taken for granted. This is best illustrated through the publicly unnoticed spheres of influence that join this ideological work together.

\section{Threading Convergences}

Our analysis is derived from our interest in meaning and its making, and its political concomitants. Here in this article, we draw methodologically on publicly available sources, including newspaper columnists, parliamentary speeches, statements by opinion-leaders, pronouncements by political leaders, and political parties. These are triangulated with each other to convince us that there is a reality to the common patterns that we extract, and the principle of 'saturation' led us to limit the data to the social phenomena that we have thus far uncovered. In the areas of social life that we examine, we provide examples from government, law, courts, policing, educational institutions, and media. This commentary and partial empirical exploration remains work in progress as there are regular occurrences in our fields of study that will continue in ongoing research to further probe and identify trends, patterns, and repetitions. In this paper we present a snapshot of what we denote as convergences, extending the work of others. For example, Akbarzadeh (2016) argues that emergence of far right groups combines with a political environment that allows anti-Islamic discourse. An emerging 
body of literature documents the ways in which Muslims and Islam are commonly depicted in the Western media, with increasing attention to the gendered nature of such depictions and prejudices. Our paper extends current approaches by looking at how these categories of far-right, political, and media feed one upon another. We begin by scrutinizing the far right and while acknowledging that emergent groups on their own may not yet have much traction in the wider community, we argue that their messages fuel confidence by the right-leaning mainstream, enabling incorporation into policy constructs. Simultaneously, the far-right gains confidence in their audacious protests against Muslims and Islam through the normalization of Islamophobia in 'respectable' spheres.

\section{Right-Wing Deplorables}

In the same month as Minister Tudge's London speech about Australian 'values', four extremists invaded a mosque in Brisbane, rifled through books, called a child a 'bloody terrorist', and threatened to burn the place down. An Islamic Council spokesman said his community was terrorized (Australian Associated Press 2018). We argue that there is a symbiotic relationship between the extremist terrorizing of Muslim communities and the purportedly liberal harrying of them-both in the name of 'mainstream' values. One month later police were investigating a fire at the Al-Taqwa mosque in Perth, which coincided with the end of Eid al-Adha. As the police investigated this suspected arson attack, community leaders were asking 'why are they hating us' (cited in The West Australian 2018). Disturbingly, such events are becoming normalized with insurance companies reported as being unwilling to insure the mosque because the risk of vandalism was deemed to be high.

We acknowledge that those we define as right-wing deplorables do not target only Muslims, as globally and in Australia racism is directed toward non-white immigrants more broadly, asylum seekers/refugees, racialized minorities, and even-in Australia perhaps especially-the nation's Indigenous peoples. Although the arguments in our paper make a contribution to the wider context ${ }^{2}$, our intent is to contribute to the burgeoning literature and research on the phenomenon of Islamophobia and our analytical method is derived from evidence in this sphere. Before moving to discussing right-wing extremism and institutional Islamophobia in detail, we provide background by locating the present within the context of post-colonial racism in Australia.

\section{Racism and the Quest for Assimilation in Australia}

White Australia has a history of racism over two centuries, and yet post-war immigration to this country was massive and enormously culturally and linguistically diverse. Each new cohort of immigrants, eventually from non-European, non-Christian, and even non-White backgrounds, was subjected to cruel Othering and discrimination. That this functioned for a time to pressure newcomers to assimilate, or to maintain their Otherness with safe imperceptibility, was long celebrated by the 'mainstream' as a happy integration into 'Australian values' (Poynting and Mason 2007). Thus, there exists in Australia the belief or perhaps hope that the latest spate of racism is but a passing phase, a rite of passage whose discomforts, once endured, will deliver the benefits of development and civilization to erstwhile 'Third-World-looking' (Hage 1998) Others. Accordingly, many believe that the vilificatory and even violent targeting of Muslims is a phase that will pass. After all, this argument goes, there were the Chinese, the Greeks, the Italians, and the Vietnamese who were Othered in their turn, and even now there's some 'onward movement' to South Sudanese, as so-called 'ethnic gangs' are invoked to criminalize and defame young people from this background (Nolan et al. 2011; Budarick 2018).

However, the focus on the 'deviant Muslim' is qualitatively different from the Othering of these successive influxes of immigrants, and it is prolonged and not subsiding. As has occurred globally, attacks on the United States in September 2001, and subsequent terrorist attacks in other countries,

2 See, for example, for the European context, Journal of Intercultural Studies 37, 6, special issue on Contemporary Far-Right Racist Populism in Europe, October 2016. 
continue to be held up to legitimize anti-Muslim activity around a number of spheres of Australian life. 'Debates' on freedom of speech as an absolute abound, such as those in defense of the supposedly brave and outspoken Charlie Hebdo after the violence visited on it by terrorists-always with the Muslim Other cast as the illiberal, censoring fundamentalist. There has been a revival of the clash of civilizations trope (Huntington 1993) - including that Muslim values are incompatible with (undefined) Australian values, as typified by the assertions of Alan Tudge (Tudge 2018) cited above.

\section{Islamophobia by Stealth}

These ideological maneuvers have positioned right-wing groupings as not only untouchable, but necessary to enable government, societal institutions, the law, and media to adopt much of the rhetoric and political thrust of these groupings, whilst distancing themselves from their 'extremism'.

This Islamophobic creep from right-wing groups to entrenched institutionalized Islamophobia challenges the view that such groups are relatively harmless and not to be taken seriously: the assumption that if we simply ignore them, they will disappear; if we challenge them, they will flourish. The view that these right-wing nationalist extremist groupings are miniscule, insignificant, and without influence might have merit if we consider each grouping separately, particularly the most strident and violent of the groups with which the bulk of the population does not identify. Skinheads, nationalist tattoos, shouted offence, and campaigning around such issues as calling for a ban on halal food, aspects which we surmise are of no interest to the majority of the Australian population. Yet these groups have a more pernicious consequence in that the minimal public resistance to their flourishing can be read by both the press and the government, even if not supporting their tactics, as support for their rhetoric and politics, leading to their reflection in Islamophobic journalism, policy, and law. Such support, although tacit at times, militates against public critical reflection when legal and policy measures that erode first generation human rights, civil liberties, are in place as the later examples of anti-terrorism laws and Countering Violent Extremism programs will illustrate.

There exists a paradox that adds a further complexity to the debate. With the emphasis on so-called Islamic extremism, right-wing extremism is minimized in public and political arenas. The attention given to what is represented as Islamic extremism is far out of proportion to its impact in Australian society, which is close to zero. However, invoking fear is a powerful mechanism for ensuring public compliance.

Although Australia has not reached the proportions of right-wing extremism witnessed in some European countries, and in the US in the Trump era, its pernicious growth is reminiscent of the rise of the acceptance of Nazi ideology in Germany, and we should keep in mind where such bigotry and hatred might lead to in political-economic crisis. Further, in an age when social media has taken hold, the reach of these groups and the rapidity of their messages have extended to levels not imagined during the rise of fascism and Nazism. Goebbels' 'big lie' appears low-tech and underpowered beside algorithm-directed 'fake news'. These groups, often known as alt-right, with their focus on anti-immigration, can be identified as anti-democratic, fascist, and neo-Nazi in intent, and they deploy patriotic and nationalistic ideologies in their incessant fixation about Muslims.

Despite their lack of direct influence, these groups have caused great harm to Muslims and to the reputation of Australia in the Muslim world, where they emerge as colonialist and white-supremacist. The Islamophobia Register, for example (Iner 2017), received disturbing reports of abuse against Muslims, particularly women, and it is likely that there is significant under-reporting (see Poynting and Perry 2007). Although the Islamophobia Register was one of the first endeavors to document empirically and systematically the practices of Islamophobia in Australia, there have been other reports that highlight the harmful impact of anti-Muslim provocations (Poynting and Noble 2004; Dreher 2005). As Ta-Nehisi Coates (Coates 2015, p. 10) writes about America's race history, 'racism is a visceral experience, that it dislodges brain, blocks airways, rips muscle, extracts organs, cracks bones, breaks teeth.' 


\section{The 'Right' Influences the 'Left'}

Somewhat paradoxically, the dichotomy of 'right' and 'left' breaks down when it comes to women's rights and it would be remiss not to take account of this when interrogating their convergence in Islamophobia. The global influence of Ayaan Hirsi Ali is a case in point. Somali-born ex-Muslim Ayaan Hirsi Ali is a former politician for the right-wing anti-immigrant Dutch political party, the Volkspartij voor Vrijheid en Democratie (VVD, or People's Party for Freedom and Democracy). She has powerful organizational and financial backing and has told her life story in four best-selling books, generalizing her own experiences to all Muslim women, despite having almost no support from Muslim women. She now sees herself as an enlightened atheist, in contrast with Muslim women whom she describes as prisoners, slaves, submissive robots, and frightened birds (cited in Briskman and Latham 2017, p. 109). The Ayaan Hirsi Ali Foundation focuses on Female Genital Cutting, Honor Violence, and Forced Marriage (Briskman and Latham 2017). One of the disturbing aspects of Hirsi Ali's influential reach is that she has captured the hearts and minds of many western feminists who would consider themselves left-leaning. The unfortunate mantra of the oppressed Muslim woman has joined up the left and the right especially through attention on the hijab and the many women who see themselves as champions of women's rights, hurtfully portraying head covering as an instrument of oppression. Even more noxious is the fear, anxiety, and sense of threat that covering invokes, particularly since September 11 (Amer 2014, p. 2). As Leila Abu-Lughod (Abu-Lughod 2013, p. 4) so eloquently explains in referring to Arab women in different countries and from all walks of life, Muslim identity is meaningful and faith in God essential for a sense of self and community.

More recently, Hirsi Ali has extended her brief. In the same week that the Tudge speech was lauded, The Australian published an extensive essay by her, in which she weighed into debates raging about the extent of so-called African crime (Hirsi Ali 2018, pp. 15, 17). Although the reality is that rates of crime perpetrated by African-background offenders in Australia are low, media and government collude again to manipulate fear and bigotry for commercial and electoral advantage. It is curious how Hirsi Ali, based in the United States, was informed about this topical issue in Australia, but less bewildering how she used the opportunity to fortify her 'culture wars' position and with the audacity to write as an insider and by proposing a typology of immigrants: adaptors, coasters, fanatics, and menaces.

However, it is as an ex-Muslim anti-Muslim that Hirsi Ali has greatest impact, in a colonial feminist turn. Hirsi Ali's partial analysis distorts the reality of Muslim women's lives, something that Muslim writer Amal Awad (Awad 2017) conveys in her treatise on similarities and differences experienced by Arab women in their daily lives. Nonetheless, reasoned, nuanced voices are drowned out by a proliferation of authors of global influence, anti-Muslim ex-Muslim women, who write in an autobiographical genre of genital cutting, honor killings, and other practices, inaccurately attributing them to Islam, that shock and that cause Islamophobic outrage in the west. In Spivak's (Spivak 1988) words, there is a tendency of white men to save brown women from brown men, and that tendency extends to women. The right-wing media in their supposed compassion for Muslim women publish articles that are dressed-up versions of the ideology of right-wing groups, talk about the oppression of Muslim women, the need to rescue them, and the scourge of the hijab. Caroline Overington (Overington 2018) from The Australian is one offender. She criticized the Department of Foreign Affairs and Trade for supporting Muslim women's entry into the international fashion industry (Hussein et al.). Former conservative Prime Minister Tony Abbott weighed in, saying modest dress contradicted Australian values, forgetting how his own 'immodest' beach attire of 'budgie-smugglers' invoked embarrassed objections, or at least considerable mirth, in 2009.

We turn now to what we contend are the most insidious forms of Islamophobia through the 'respectables'. We begin with government and politics, and then provide examples from arms of government, including laws, courts, and policing. We then turn to educational institutions as reinforcing Islamophobia, and finally provide an overview of media and social media influence. 


\section{Politics and Government}

In the field of politics and government, Islamophobia has stealthily overtaken institutions once far too respectable to tolerate its influence. It has become unnoticed, taken for granted, the new normal.

At the parliamentary extreme, an offensive Islamophobic stunt in 2017 by One Nation Senator Pauline Hanson, entering the Senate chamber clothed in a burqa and there removing it, in a shameless quest for publicity, succeeded in that aim. While Hanson indeed attracted broad-based opprobrium and ridicule for this act, it was notable that her reproof by then Attorney General George Brandis, widely praised for its principle and wisdom, in fact condemned Hanson not so much for the gratuitous offence to Muslims, as for undermining the Australian government's good relations with Muslim communities in their attempts at countering Islamic terrorism. The Hanson extreme offered convenient 'cover' for the governmental common sense about the dangers of Muslim political violence.

In 1996, when Pauline Hanson was elected as the member for Oxley, she was widely regarded as beyond the pale for promoting unacceptable racism, with her railing against immigration and multiculturalism, 'special privileges' for Aborigines, and Australia being 'swamped' by Asians. She was despised by media commentators, though she got plenty of their attention and made good copy, and she was officially shunned by the major political parties. Her anti-Muslim racism at the time was less noticeable, since it was less emphasized, but it was certainly brought to the fore in the 2001 election campaign, when Prime Minister Howard's ministers were making similar pronouncements. By the time Hanson was elected to the Senate in 2016, there was a new approach from media pundits and political leaders. That was to treat her with the respect they argued was due to the office to which she was elected, and thereby to avoid disparagement of those who supported and elected her. Hanson's first Senate speech complained of Australia being 'swamped by Muslims'. The racism was as egregious as two decades ago, but the racialized Other was now a global folk devil demonized across the western world. The populace had shifted towards nationalism and xenophobia, and right-wing populism was increasingly taken for granted. Hanson had gone from being seen as extreme and on the far right to being viewed rather as merely a politician, albeit a right-wing, erratic, and rather ridiculous one-almost normal in the Trump era.

The attack on what used to be called 'political correctness', which was there in the 1996 election campaign when Hanson was first elected, was part of this rehabilitation of racist discourse. John Howard's dog-whistling maneuver was to say that he did not endorse Hanson's stances on immigration and multiculturalism and the like, but that she did speak for a lot of people and that they had a right for their views to be treated seriously. This strategy of 'anti-anti-racism' was quite international, and the tactics were imported wholesale from the United States. It was deployed effectively here in the (to date unsuccessful) battle to repeal Section 18C of the Racial Discrimination Act (banning certain forms of racist offensive behavior), in which then Attorney-General George Brandis asserted that Australians had the 'right to be bigots' (cited in Chan 2014). Racial vilification that was shameful and unacceptable in, say, 1996, was now to be celebrated as some sort of human right, a courageous forthrightness and valiant exercise of free speech. The fact that the outgoing Senator Brandis could be so celebrated upon his departure from parliament in February 2018 in airing differences with his illiberal cabinet rival, Home Affairs Minister Peter Dutton, is an indication of how far Australian politics has moved to the right.

As Immigration Minister, Dutton had opined, in a parliamentary debate in 2016, that it had been a mistake to settle so many Muslim Lebanese in Australia in the 1970s. In the same role, Dutton had, from 2015, been responsible for a humanitarian entrants policy that manifestly favored (despite the objections of the United Nations) Christian Syrians and Iraqis over the majority Muslims, by classifying them as 'persecuted minorities' (Kenny and Wroe 2015); this discriminatory policy was also supported by senior ministers Turnbull and Abetz. Dutton's assertion that those selected would more readily integrate into Australia made the bias clear. This overt shift away from non-discriminatory immigration policy marks a profound departure from norms in place since the 1970s, and attests to the influence in Australia of anti-Muslim right-wing populism. 
Not long after Tudge's outburst in England, little-known candidate Fraser Anning took his seat in the Senate. Anning became a senator on the ticket of Pauline Hanson's One Nation party after one of their elected senators was retrospectively ruled ineligible. Before acceding to parliament, Anning defected to the Katter's Australian Party, a newer right-wing populist and economically nationalist party in parliament. Anning's maiden speech to parliament shook up even pluralism sceptics by calling for a 'final solution' on immigration. Not only did he adopt that historically disgraced term, but he made clear who were the racialized 'Others' in question by advocating a ban on Muslims settling in Australia, and he further called for resumption of discrimination in immigration based on race in a reversion to 'White Australia' (cited in Koziol 2018). Party leader Bob Katter stood by Anning's diatribe, thus confirming the presence of two racist minority parties in the Australian parliament. Prior to the advent of Hanson, this sort of rhetoric had been unheard of in the Australian parliament for at least thirty years. Shunned though Anning (and possibly now Katter) may be, the very possibility of such a parliamentary speech confirms the institutionalization of Islamophobia in contemporary Australia. Notably, the Senate declined (in defeating the Greens' motion) to censure Senator Anning for his racism and espousal of unlawful discrimination. It is notable that much of the condemnation of Anning, including from then Prime Minister Malcolm Turnbull, focused on his use-supposedly in ignorance - of the Nazi term 'Final Solution'. The racial supremacist overtones, and the intention to exclude Muslims from the nation, were not a major focus of the opprobrium.

Just over a week after Anning's maiden speech, an inner-party coup saw Malcolm Turnbull replaced as Prime Minister. Though his primary challenger, Peter Dutton, was unsuccessful, the maneuver saw the appointment of a new prime minister: Scott Morrison, like Dutton a right-wing Christian, former immigration minister, and virulent opponent of maritime-arrival asylum seekers.

Back in 2011, as Shadow Minister for Immigration, Morrison had encouraged the shadow cabinet to take advantage of what he saw as the electorate's worries over 'Muslim immigration', Muslims in Australia, and the supposed inability of Muslim immigrants to integrate. He had railed against the cost to the state of funerals for Iraqi and Iranian asylum seekers drowned at Christmas Island in December 2010, even as those funerals were taking place (Taylor 2011). Rebuked at that time by his party, he is now its leader, and thereby Prime Minister.

Amid ceaseless 'debate' about 'Australian values' and suitability for integration into Australian society, the government attempted in 2017 to introduce extremely restrictive citizenship legislation (Dziedzic and Belot 2017), including the requirement of English language proficiency of university level. Though the attempt was not successful for lack of a Senate majority, there was harmful social division promoted by its proposals for a 'values-test' to be incorporated into the existing citizenship test, whereby it was planned to ask such provocative and ill-informed stereotypical questions as whether migrants supported genital cutting, forced marriage, and domestic violence. In proposing such a test, populist politicians were taking on agendas of groups, such as the right-wing nationalist and openly Islamophobic Reclaim Australia, with its call for a Pledge of Allegiance. In his speech in the UK, Citizenship Minister Tudge alluded to values testing, positing that values are 'the glue that holds a nation together' (Benson 2018, p. 1). For Offord et al. (2014, p. 33), in contemporary Australia values are sustained through 'a matrix of power relations that were established through the installation of Enlightenment.' In political discourse we see this played out in such statements as those uttered by Senator Anning by proposing that 'diversity should be managed to remain compatible with social cohesion and national identity ... We as a nation are entitled to insist that those who are allowed to come here predominantly reflect the historic European-Christian composition of Australian society' (cited in Koziol 2018).

Thus the 'values debate' serves as a thin veneer of respectability for outright cultural supremacism, oppressive assimilationism, and stark racism. As the outgoing Race Discrimination Commissioner, Tim Soutphommasane (Soutphommasane 2018) observed in his valedictory speech, 'Where the seeds of racism are planted in political speech, they will bear bitter fruit in society.' 


\section{Law, Courts and Police}

The legal system is seen as the cornerstone of upholding democratic values, justice, and fairness. Similarly, a robust and effective police force is accepted by most in our society as necessary to ensure that the rule of law is maintained and that community safety is paramount.

Yet despite these lofty ideals, there has been no shortage of Islamophobia within the law and the criminal justice system in Australia. We saw the hurried introduction after September 11 and since then the continual ramping up of anti-terrorism legislation that denies the presumption of innocence and is antithetical to civil liberties and basic human rights. Although this is not unique to Australia, most western liberal democracies have the protection of human rights legislation, that is absent in Australian society. According to George Williams (Williams 2011), Australia had passed over sixty pieces of anti-terrorism legislation since 9/11: more than other countries. The Howard Government alone between September 2001 and its departure from office in 2007, enacted 48 new anti-terror laws: one new law on average every 6.7 weeks.

The plethora of anti-terrorism laws in Australia has been so broad in scope and their enforcement has been so targeted at particular groups that breaches of human rights have ineluctably followed. Terrorism is routinely equated with Muslims expressing opposition to, or radical difference from, 'mainstream' society. Terrorism investigations, charges, trials, and convictions have, with very few exceptions, involved Muslim men (Dagistanli and Poynting 2017). In this context and given the 'pre-crime' (McCulloch and Wilson 2015), preventative aspect of counter-terror legislation, this targeting practically amounts to criminalizing Muslim communities. As Dagistanli and Poynting (2017) observe:

Men and women who visibly practice Islamic faith are at risk of being accused of, and punished without trial for, alleged terrorism offences by virtue of their likely association with other Muslims who may have family links to other individuals in the same geographical area as a terrorist organization. They risk being blamed for terrorism if they have religious affiliations with organizations that have been popularly associated with terrorist sympathies. The links are often tenuous, exacerbating the risk of innocent Muslims being blamed, punished, and caught within the broad net of the counter-terrorism laws.

Since the deployment of these counter-terrorism laws, there have been miscarriages of justice, false arrests, wrongful detentions, as well as unlawful intimidation and even kidnap perpetrated by federal police and security agents (see Dagistanli and Poynting 2017, for but a few brief examples).

Soon after the 9/11 attacks in the United States, armed police and security agents conducted high profile and heavily publicized pre-dawn raids on Muslim households across various Australian suburbs: Doors were smashed in, children were menaced with automatic weapons, innocent families were subjected to gratuitous violence and humiliation. There were no arrests for terrorism-related offences (Poynting et al. 2004). Similar raids were perpetrated a year later after the Bali terrorist bombings, and again after the London transport bombings in 2005.

Again in September 2014, in the context of a security panic and well-fed media frenzy about an alleged plot to decapitate a random stranger in the street, there were raids by some 800 Australian police and security agents on the homes of Australian Muslims in the state capital cities of Brisbane and Sydney. These raids took place five days before the mentally disturbed 18-year-old former asylum seeker from Afghanistan, Numan Haider, was shot in the head by police during a confrontation in Melbourne (Poynting and Briskman 2017). Haider was later accused posthumously of plotting a beheading in a public place; no charges were ever proffered for this far-fetched plot, and the need for a trial was precluded by his death at the hands of the state. The 2014 counter-terrorism swoop constituted the biggest coordination of such raids in Australia's history: far larger than those of 2001, 2002 and 2005. Highly publicized and mediated, as were the earlier rounds, the anti-terror raids of 2014 saw but one terrorism charge proffered: Against Omarjan Azari, who remains in jail in 2018, after his trial was aborted in 2017 because of judicial concerns about media reports prejudicing it. His maximum-security conditions occasioned objections by a supreme court judge in 2015 for the 
prisoner's inability to access lawyers effectively to prepare his defense (Hall 2015). Azari stands charged with 'doing acts in preparation to commit a terrorist act' under anti-terror laws that leave ample ambit for prosecutions to construct a scenario with little and circumstantial evidence, as the future act allegedly prepared for does not need to be specified or indeed achievable by the accused (Dagistanli and Poynting 2017).

The 'incremental creep' of Islamophobia into anti-terrorism laws is disturbing in a country that does not have checks and balances through human rights legislation. The introduction of measures that restrict civil liberties are not challenged by frightened populations (Fawzi 2015), with the fear propagated by government and associated media discourses functioning effectively to keep them acquiescent. This is how racism works, says recently retired Race Discrimination Commissioner Tim Soutphommasane (Soutphommasane 2018): 'It creates doubts and divisions and it drives its targets into retreat.'

The theatrics of the courtroom, though formally free from prejudice, are not above Islamophobic gestures. Lawyer Duncan Fine (Fine 2018) commented in The Sydney Morning Herald newspaper on how a judge of the Victorian Supreme Court banned a woman wearing a niqab from sitting in the public area of the court where her husband was on trial for terrorism charges. As Fine pointed out, judges often wear ornate horsehair, wigs, and flowing red and purple gowns in the courtroom so what is offensive about the niqab, especially when the woman in question was not a participant in proceedings? The leader of the Victorian opposition, Matthew Guy, bought into the performance, declaring, 'If you don't respect the court, you don't respect the law' (cited in Fine 2018). There was a similar circus in 2010, when a revert to Islam, Carnita Matthews, wearing a niqab (denoted by Murdoch's Daily Telegraph as a 'burqa') in court, was sentenced to six months imprisonment for falsely accusing a police officer of removing her veil after her car had been stopped by police and she had been contrived to be fined on a manifestly fallacious charge of not properly displaying a provisional driver's license plate (Vollmer and Klein 2010). This verdict was in 2011 overturned on appeal to the NSW District Court, but the law was amended later that year to provide for removal of drivers' face veils, and indeed on face cover in courts and prisons. The amendment came after a strident campaign by none other than the Daily Telegraph.

Anti-terrorism laws do not work in isolation. The following example of Countering Violent Extremism policies and programs, initiated and funded by government, illustrates the tenaciousness of the reach of institutional Islamophobia.

\section{Countering Violent Extremism}

As the years since the 2001 attacks on the United States have receded, the militarized discourse and associated actions of the War on Terror in Australia have somewhat diminished. The replacement has been a differently focused lens on Muslims through Countering Violent Extremism (CVE), and with global reach (see Kundnani 2009, 2014; Aked 2017). The CVE narrative has metamorphosed into an expanding industry, which shifts responsibility for detecting and isolating Muslims deemed to present a threat to society toward an abstract notion of community.

Professional bodies in Australia have been co-opted into programs and offered significant amounts of money to train up their members in CVE and 'de-radicalization'. These programs are deceptively couched in terms, such as community cohesion and resilience, and camouflaged by rhetoric that declares ideological neutrality and attention to all forms of extremism. This ideological neutrality claim is unconvincing. In the parallel British Prevent program, discussed below, ideology is explicitly named, stated by government to be central factor in the radicalization process (Coppock and McGovern), whereas in Australia it is masked behind 'soft rhetoric'. A confusing array of programs that use 'softer' terms as noted above can serve to mask the dominance of a de-radicalization and surveillance agenda. As in the UK, a vulnerability discourse is invoked in CVE programs, that is divorced from structural analyses of lived experiences. In Britain, discourses of child protection become securitized to underpin intervention and surveillance, providing a narrative of radicalization and extremism that 
render Muslim youth as suspects (Coppock and McGovern). A psychological paradigm is privileged with behavioral indicators that are dubiously linked to the ability to predict suspect behavior through a pathologizing approach.

By way of example, the Australian Association of Social Workers received government funds to run CVE programs for social workers. In 2018, 350 social workers have attended sessions as part of professional development activities, although it is highly unlikely that social workers would encounter aspiring terrorists. These sessions will continue in 2019. A somewhat dubious matrix to determine a propensity to violent extremism is elevated to biblical proportions in the training. The efficacy of the training has not been established and there are no clear indications about what value it could have. For social workers in areas of practice, such as child protection or mental health, we surmise that the attraction of the program is not to spot a terrorist but merely to gain professional development points. However, of the most concern is the ethical question of collusion with state crafted policies that likely contradict the social justice values enshrined in social work and other professions, as well as the principle of confidentiality.

Schools are under scrutiny. In late 2015, the New South Wales government introduced a suite of measures worth $\$ 47$ million targeted at training school staff in skills to identify 'vulnerable' young people. The programs received criticism that suggested that they would isolate at risk children, that raising suspicion by teachers was not useful, and that the atmosphere of fear and suspicion resulted in exaggerated risks from radicalizing and terrorism leading to the criminalization of the entire Muslim community (Australian Muslim Times 2015).

Moreover, problematic is the notion of community outreach and engagement with Muslim communities which underpins counterterrorism work in Australia and other countries, with an expectation that Muslim organizations will take a lead in this sphere (Cherney and Murphy 2017). As Cherney and Murphy (2017) point out, since 9/11 Muslims believe that their communities are under siege, and this is exacerbated by the introduction of a large number of counter-terrorism laws. Alongside this, CVE programs that predominantly focus on prevention, raise the risk of stigmatizing whole communities (Harris-Hogan et al. 2016).

Globally, CVE and de-radicalization programs have received criticism, the most prominent being directed at Prevent, which has taken hold in the United Kingdom and contributes to the festering hostility toward Muslims (Kundnani 2009, 2014). Among the trenchant opponents are civil society groups, suggesting that Prevent is 'the biggest spying operation of all times' (Jones et al. 2016), and expressing concern at the rise of hate crimes against Muslims. Referrals to the Prevent program have revealed an environment within which Muslim children, often on the most minor of matters, are viewed through a securitized lens, as and in doing so showing disregard for the welfare of children (Prevent Watch 2018).

Although CVE training and reporting are not currently mandatory in Australia, we need to be alert to this prospect in the future, and to be wary of playing into the hands of those working in risk-averse bureaucracies (Latham 2018). The CVE paradigm has reached into different arms of government and professional bodies and has been embraced in academic endeavors. This is by no means confined to Australia and the UK. In Canada, for example, a network of security governance actors has been formalized into a Combating Violent Extremism Group, targeting 'homegrown' terrorism, and adopting discourses of radicalization and violent extremism. Monaghan (2014) argues that concern to free people from fear or threat has justified an expansion and widening of the security agenda into the field of the social. This includes the education system at all levels, which although never value-neutral, has now extended into a concerning sphere of state collusion with Islamophobia.

\section{Education}

The entry of Islamophobia into the education sphere has many guises, including as noted above in Countering Violent Extremism programs. However, our concerns extend beyond CVE. In one controversial instance, the principal of a Sydney state secondary school with a Muslim majority, 
Punchbowl Boys High School, was removed without being given a reason, by the Department of Education. The principal, Chris Griffiths, is a revert to Islam, and had, according to the secretary of the Education Department, Mark Scott, 'been reluctant to implement the School Communities Working Together program' (Smith 2017), a New South Wales CVE program. The Sunday Telegraph (the Murdoch newspapers were staunch proponents of the program) described Working Together as 'a Baird [Liberal] government initiative to prevent students being brainwashed by Islamic extremists' (Silmalis 2017). Mark Scott is a former Liberal Party staffer and education adviser. It was he who had 'raised concerns about the school' with the education minister, and who bore responsibility for Griffiths' removal (Silmalis 2017). The whole episode bore striking resonance with the 'Trojan horse' schools scandal in Britain, which proved to be an Islamophobic beat-up with damaging and divisive consequences for the schools' communities. Whatever the full reasons behind Griffiths' sacking as principal, the fact is that he was replaced by a former teacher at a juvenile detention center, who pointedly pledged to promote 'Australian values' in the school. The Murdoch press trumpeted triumphantly at his renewal of a flagpole in the school, and daily flying of the Australian flag. In a gesture recently echoed in an Islamophobic intervention in Switzerland, those national values involved shaking hands as a sign of 'respect' for teachers.

In the state of New South Wales, there is Department of Education policy (clearly targeted at Muslims) requiring students to record when they pray during school hours (Olding 2015). Teachers hence become collaborators in surveillance-a point that has been made in the United Kingdom over the requirements for academics to perform a similar function.

Peter Dutton has held the Immigration portfolio in the Australian parliament since December 2014, and as a prime ministerial aspirant ventured into education and other portfolio areas. A former Queensland police officer, Dutton has come under persistent criticism from the refugee advocacy movement for his harsh asylum seeker policies, particularly the incarceration of children in offshore detention. In the education sphere he has 'used children to start a sly war over nationalistic values' (The Saturday Paper 2018, p. 14) by arguing that children should 'talk more about our story, about our history and our core values'. In this respect, he was closely following the model of former Liberal Prime Minister John Howard, and his ministers, notably Education Minister Brendan Nelson in 2005.

The media are quick to pick up on incidents in schools to argue the clash of cultures refrain. A seemingly minor matter reached headline proportions in 2015, when a group of Shia Muslim children were given permission not to participate in the singing of the Australian national anthem during the holy month of Muharram, when they traditionally refrain from singing (Jefferson 2015). 'ANTHEM OUTRAGE', hyperventilated the Daily Telegraph on its page one, asserting mischievously and misleadingly, 'Muslim students walk out on national song'.

In weighing into the same minor moral panic, right-wing education think-tank director Kevin Donnelly, who chaired the 2014 review of national curriculum commissioned by the Liberal-National government, equally misleadingly announced in his media intervention that, 'Submissions to last year's review of the Australian national curriculum argued in a similar vein: that in subjects like history and civics, students should be taught that Australia is a secular society with a strong Judeo-Christian heritage, unlike theocratic societies like Iran and Saudi Arabia' (Donnelly 2015). With the agility of a practiced propagandist, he did not say how many submissions, or whether most so argued.

In 2018, divisive politics erupted at university level over the bequest of a significant amount of money targeted at a university to be selected to run courses on western civilization, consistent with Tudge's call for a 'muscular' defense of western liberal values, cited earlier. The Ramsay Centre for Western Civilization was launched in November 2017, offering substantial funding to a small number of Australian universities. Consistent with his views on the importance of Judeo-Christian heritage and Enlightenment thought, former conservative Prime Minister and Chair of the Ramsay Centre, John Howard, stated that the new offerings would give students the opportunity to study 'that extraordinary civilizational heritage', echoed by another former conservative Prime Minister Tony 
Abbott who spoke positively of the legacy of benefactor Paul Ramsay on the Golden Age that will enable us to 'hold on to the values that have made this country great' (Ramsay Centre 2018).

The favored contender for the funding, the prestigious Australian National University, pulled out of the bid when it appeared that the courses would be subject to scrutiny and would minimize academic autonomy. The Vice-Chancellor and Chancellor of the university both noted an 'extraordinarily prescriptive micromanagement approach to the proposed program' (cited in Karp 2018). The next favored contender, The University of Sydney, also became embroiled in controversy with some academics labelling it as 'European supremacism writ large' (cited in Urban 2018) and with student protesters also opposing the bid. At the time of writing, there has been no resolution.

At its most benign level, the bequest could be seen as bolstering the declining humanities by instilling an appreciation of schools of historical, philosophical thought, and classical literature. Yet privileging the somewhat outmoded concept of 'western civilization' is harmful to the cultural diversity that is today's Australia. If the Ramsay Centre offers the more liberal, respectable version of the 'culture wars', its proposals come in the context of Pauline Hanson's more baldly Islamophobic warnings of Muslims' supposed hatred for 'western society' (Gartrell 2017), and their regular echoes in the Murdoch press that has been championing the Ramsay Centre intervention in education. It builds on other politicized attempts to influence education curriculum (such as the review mentioned above conducted by Donnelly and business academic Ken Wiltshire), including former Prime Minister John Howard's earlier call in 2006 to renew the position of Australian history in the curriculum and promote the teaching of the national story narrative. In 2014, it was conservative government concerns that national curriculum was not affording sufficient value to 'western civilization' (Cairns 2018), which led to the controversial and divisive review of the national curriculum.

\section{Media}

In the sections above, we have shown how the mainstream right-leaning media have increasingly influenced the offensive on Muslims, through commentary on many facets of public life and through a penchant for misleading headlines and stories that fuel fear and prejudice in uncritical sections of the community. In this final section of our article, we provide examples that illustrate the persistence of media influence and how conventional and social media create a climate of moral panic. We primarily refer to mainstream media in its many forms, including print, television, and radio.

In a survey of Arab and Muslim Australians for the Human Rights and Equal Opportunity Commission in 2004, the media was the second most frequently cited 'place' of racism and abuse (after 'the street') nominated by respondents. Nearly half (47\%) of respondents to the questionnaire returned by 200-odd in Sydney and Melbourne, had experienced racism in the media, with Muslim respondents reporting media racism more than non-Muslims (Poynting and Noble 2004). The qualitative phase of that research project found:

The ideology of 'Lebanese terrorizing Sydney', or of women being oppressed by Muslim men, of the hijab being an affront in a 'Christian country' or a civilized society, and the like, has been circulating for several years in the popular media, especially the tabloid press and commercial talkback radio. ... Many ... respondents saw such media vilification as inciting the very racial hatred they were suffering.

The same process was reported thirteen years later in the Islamophobia Register Australia (Iner 2017, p. 77). Kevin Dunn and his co-authors found in 2015 that 79\% of their random sample of Muslims living in Sydney believed that the Australian media portrayed Muslims unfairly; some 83\% believed that media reports influenced non-Muslims' views about Muslims (Dunn et al. 2015).

Islamophobia, then, persists in the Australian media, has done so for most of two decades (and indeed arguably three), and is perceived by those targeted to engender racist hatred against them. This chronology means that a whole generation has grown up in these circumstances; they have not experienced Australian society otherwise. That is one sense in which it is becoming normalized. 
Yet it is also intensified. While sporadic outbreaks of anti-Muslim moral panic did the rounds of the Australian mainstream media in the early years of this millennium, depending on trigger events, this is now virtually weekly fare in the Murdoch press and on his Sky Channel, on other commercial television, and talk-back radio programs, and not just commercial media outlets. In the last week of August 2018, the state-funded national broadcaster, the Australian Broadcasting Commission, aired its popular participatory panel discussion program $Q \mathcal{E} A$ with an all-white panel of five politicians. Among these, it gave a platform to the leaders of both demonstrably racist parties now represented in parliament: Pauline Hanson and Bob Katter, as if they were a reputable part of the body politic, to discuss (prominently among other topics) Fraser Anning's maiden speech to the senate advocating a return to 'White Australia' and a 'final solution' to immigration issues. This is the new normal.

Beyond the mainstream media, as the Islamophobia Register Australia makes apparent, Islamophobic vilification on the internet, particularly via 'social media', is now constant and intensive, with 'alternative facts' abounding and rebounding. Anti-Muslim hate speech is particularly acute online, with the spread of anti-Muslim hate becoming viral at times (Oboler 2016). Social media takes many forms and one of the most influential is Facebook, given its wide reach and ease of usage. Moreover, largely free of regulation or sanction that might dampen incivility or hate-mongering, the internet speeds up, as well as intensifies, the cycles of racialized folk-demonization. These media feed off the traditional media, and vice versa, as the engagement with $Q \mathcal{E} A$ makes clear.

To provide such an audience for outright racist politicians would have been highly unlikely in the quality Australian media of a generation ago; nor would their views have been entertained as meriting serious consideration.

\section{Conclusions}

We end on a somewhat pessimistic note, not dissimilar to where we began. As we have argued, Islamophobia has progressed from a fringe element in Australian society to a position of respectability through its institutionalization in public and private spheres. There is not one area of public policy that is untouched, escalating in scope since nine cabinet members of the Australian parliament in 2015 made statements about terrorism or proposed initiatives to tackle it (Latham and Briskman 2015). As alluded to throughout our piece, ideological scapegoating of Muslims has become normalized and in Gramscian terms entrenched in 'common sense', made respectable through formal and informal partnerships of government with media, institutional, and professional actors. Right-wing groups that operate in both the public and social media realm, now have their mission taken up by 'the respectables', including parliamentary representatives, architects of new laws, academics, teachers, and social workers. Calling out Islamophobia by groups with vested interests, does not yield responses that reverse the trend. For Australia in its geographic isolation, there appears to be a 'me too' approach that makes no logical sense given that Australia is a safe, secure, and prosperous country, despite what Islamophobia pundits wish to convey.

Even harder to dislodge than institutional connection and collusion are discourses that have taken hold since $9 / 11$ of the 'dangerous, deviant Muslim', with the specter of terrorism ever-lurking. With each media pronouncement, fear and anxiety levels are elevated, with no concern about the fears imposed on Muslims and for their wellbeing and safety. Increasing conservative trends diminish the multicultural project of Australia, whilst at the same time operating under a pretext of harmony, inter-faith, and social inclusion.

Author Contributions: Each of the authors has contributed equally to the production of this article, in all of its aspects.

Funding: This research received no external funding.

Conflicts of Interest: The authors declare no conflicts of interest. 


\section{References}

Abu-Lughod, Lila. 2013. Do Muslim Women Need Saving? Cambridge: Harvard University Press.

Akbarzadeh, Shahram. 2016. The Muslim Question in Australia: Islamophobia and Muslim Alienation. Journal of Muslim Minority Affairs 36: 323-33. [CrossRef]

Aked, Hilary. 2017. Islamophobia, Counter-extremism and the Counter Jihad Movement. In What Is Islamophobia? Racism, Social Movements and the State. Edited by Narzanin Massoumi, Tom Mills and David Miller. London: Pluto Press, pp. 163-85.

Amer, Sahar. 2014. What Is Veiling? Chapel Hill: The University of North Carolina Press.

Australian Associated Press. 2018. "Our community is terrorised": Muslims abused as men invade Brisbane mosque. The Guardian, July 5. Available online: https:/ / www.theguardian.com/australia-news/2018/jul/ 05/our-community-is-terrorised-worshippers-abused-at-brisbane-mosque (accessed on 13 August 2018).

Australian Muslim Times. 2015. Program to Counter Violent Extremism. Amust, November 5. Available online: http:/ / www.amust.com.au/2015/11/program-to-counter-violent-extremism-2/ (accessed on 3 September 2018).

Awad, Amal. 2017. Beyond Veiled Cliches: The Real Lives of Arab Women. Sydney: Vintage Books.

Benson, Simon. 2018. Values Test Flagged for Migrants. The Australian, July 20, 1.

Briskman, Linda. 2015. The Creeping Blight of Islamophobia in Australia. International Journal for Crime, Justice and Social Democracy 4: 112-21. [CrossRef]

Briskman, Linda, and Susie Latham. 2017. Refugees, Islamophobia and Aayan Hirsi Ali: Challenging Social Work Co-option. Affilia: Journal of Women and Social Work 32: 108-11. [CrossRef]

Budarick, John. 2018. Why the Media are to Blame for Racialising Melbourne's 'African gang' problem. The Conversation, August 1. Available online: https:/ / theconversation.com/why-the-media-are-to-blame-forracialising-melbournes-african-gang-problem-100761 (accessed on 3 September 2018).

Cairns, Rebecca. 2018. Western Civilisation? History Teaching Has Moved On and So Should Those Who Champion It. The Conversation, June 6. Available online: https:/ / theconversation.com/western-civilisationhistory-teaching-has-moved-on-and-so-should-those-who-champion-it-97697 (accessed on 5 July 2018).

Chan, Gabrielle. 2014. George Brandis: People Have the Right to be Bigots. The Guardian, March 24. Available online: https:/ / www.theguardian.com/world/2014/mar/24/george-brandis-people-have-the-right-tobe-bigots (accessed on 3 September 2018).

Cherney, Adrian, and Kristina Murphy. 2017. Police and Community Cooperation in Counterterrorism: Evidence and Insights in Australia. Studies in Conflict and Terrorism 40: 1023-37. [CrossRef]

Coates, Ta-Nehisi. 2015. Between the World and Me. Melbourne: Text Publishing.

Coppock, Vicki, and Mark McGovern. 2014 'Dangerous minds'? Deconstructing Counter-Terrorism Discourse, Radicalisation and the 'Psychological Vulnerability' of Muslim Children and Young People in Britain. Children and Society 28: 242-56. [CrossRef]

Dagistanli, Selda, and Scott Poynting. 2017. Terrorism and Anti-Terrorism Laws in Australia. In The Palgrave Handbook of Australian and New Zealand Criminology, Crime and Justice. Edited by Antje Deckert and Rick Sarre. Cham: Palgrave Macmillan, pp. 331-45.

Donnelly, Kevin. 2015. Singing the National Anthem at School Should Be Compulsory. The Age, October 27. Available online: http:/ / www.theage.com.au/comment/singing-the-national-anthem-at-school-shouldbe-compulsory-20151027-gkja8z.html (accessed on 26 August 2018).

Dreher, Tanja. 2005. Targeted: Experiences of Racism in NSW after September 11, 2001. UTS Shopfront Monograph Series, No. 2. Broadway: UTS ePRESS.

Dunn, Kevin M., Rosalie Atie, Virginia Mapedzahama, Mehmet Ozalp, and Adem F. Aydogan. 2015. The Resilience and Ordinariness of Australian Muslims: Attitudes and Experiences of Muslims Report. Penrith: Western Sydney University. Available online: http:/ / www.westernsydney.edu.au/_data/assets/pdf_file/0003/990129/ Sydney_Muslims_report.pdf (accessed on 30 August 2018).

Dziedzic, Stephen, and Henry Belot. 2017. Australian Citizenship Law Changes Means Migrants Will Face Tougher Tests. ABC News, April 20. Available online: http:/ / www.abc.net.au/news/2017-04-20/migrantsto-face-tougher-tests-for-australian-citizenship/ 8456392 (accessed on 5 September 2018).

Fawzi, Salua. 2015. Social and Political Islamophobia: Stereotyping, Surveillance and Silencing. In Routledge Handbook of Islam in the West. Abingdon: Routledge, pp. 229-43. 
Fine, Duncan. 2018. When Judges Wear Wigs and Robes, What's So Offensive about a Niqab? Sydney Morning Herald, February 8. Available online: https:/ / www.smh.com.au/opinion/when-judges-wear-wigs-androbes-whats-so-offensive-about-a-niqab-20180208-h0vs9a.html (accessed on 2 September 2018).

Gartrell, Adam. 2017. Pauline Hanson Blasts Muslims, Praises Putin, Questions Vaccines in ABC Interview. Sydney Morning Herald, March 5. Available online: https: / / www.smh.com.au/politics/federal/pauline-hansonblasts-muslims-praises-putin-questions-vaccines-in-abc-interview-20170305-guqxrd.html (accessed on 26 August 2018).

Gramsci, Antonio. 1971. Selections from the Prison Notebooks of Antonio Gramsci. Edited and Translated by Quintin Hoare and Geoffrey Nowell Smith. New York: International Publishers.

Grattan, Michelle. 2018. Soutphommasane Says Sections of Media Exploit Racism to Make Money. The Conversation, August 6. Available online: https: / / theconversation.com/soutphommasane-says-sections-of-media-exploitracism-to-make-money-101090 (accessed on 13 August 2018).

Hage, Ghassan. 1998. White Nation: Fantasies of White Supremacy in a Multicultural Society. Sydney: Pluto Press.

Hall, Louise. 2015. Judge Questions Why Terrorism Accused Omarjan Azari is on Remand in Supermax. Sydney Morning Herald, August 20. Available online: www.smh.com.au/nsw/judge-questions-why-terrorismaccused-omarjan-azari-is-on-remand-in-supermax-20150820-gj3go3 (accessed on 29 August 2018).

Harris-Hogan, Shandon, Kate Barrelle, and Andrew Zammit. 2016. What is Countering Violent Extremism? Exploring CVE Policy and Practice in Australia. Behavioral Sciences of Terrorism and Political Aggression 8: 6-24. [CrossRef]

Hirsi Ali, Ayaan. 2018. Out of Africa, Out of Bounds. Weekend Australian, July 21-22, p. 15.

Huntington, Samuel. 1993. The clash of civilizations? Foreign Affairs 72: 22-49. [CrossRef]

Hussein, Shakira, Scheherazade Bloul, and Scott Poynting. Forthcoming. Diasporas and Dystopias on the Beach: Burqini Wars in France and Australia'. In The Routledge Handbook: Key Readings in Islamophobia. Edited by Irene Zempi and Imran Awan. London: Routledge.

Iner, Derya, ed. 2017. Islamophobia in Australia 2014-2016. Sydney: Centre for Islamic Studies and Civilisation, Charles Sturt University.

Jefferson, Andrew. 2015. Anthem Outrage. Daily Telegraph, October 27, p. 1.

Jones, Jenny, Arun Kundnani, Douglas Chalmers, Shelly Asquith, Malia Bouattia, Imran Khan, Michael Mansfield, Geoffrey Bindman, Omar Barghouti, Adam Gearey, and et al. 2016. Prevent Isn't Making Anyone Safer. It is Demonising Muslims and Damaging the Fabric of Trust in Society. Letter. The Guardian, February 11. Available online: https:/ /www.theguardian.com/politics/2016/feb/10/prevent-isnt-making-anyone-saferit-is-demonising-muslims-and-damaging-the-fabric-of-trust-in-society (accessed on 9 September 2018).

Karp, Paul. 2018. ANU Accuses Ramsay Centre of Wanting 'Effective Veto' over Western Civilisation Degree. The Guardian, June 26. Available online: https://www.theguardian.com/australia-news/2018/jun/26/ramsaycentre-for-western-civilisation-wouldnt-guarantee-academic-autonomy-anu-says (accessed on 12 August 2018).

Kenny, Mark, and David Wroe. 2015. Australia Looks Set to Start Bombing Syria as Libs Warn Against Too Much Refugee Compassion. Sydney Morning Herald, September 8. Available online: https:/ / www.smh.com.au/politics/federal/australia-looks-set-to-start-bombing-syria-as-libs-warn-againsttoo-much-refugee-compassion-20150908-gjhttz.html (accessed on 13 August 2018).

Koziol, Michael. 2018. Senator Honours White Australia Policy in First Speech and Calls for 'Final Solution' on Immigration. Sydney Morning Herald, August 14. Available online: https://www.smh.com.au/politics/ federal/senator-honours-white-australia-policy-in-first-speech-and-calls-for-final-solution-on-immigration20180814-p4zxhr.html (accessed on 17 August 2018).

Kundnani, Arun. 2009. Spooked! How Not to Prevent Violent Extremism. London: Institute of Race Relations.

Kundnani, Arun. 2014. The Muslims Are Coming! Islamophobia, Extremism and the Domestic War on Terror. London: Verso.

Latham, Susie. 2018. Countering Violent Extremism Training is Institutionalising Islamophobia. Blog on the Power to Persuade, August 23. Available online: http:/ /www.powertopersuade.org.au/blog/countering-violentextremism-training (accessed on 20 August 2018).

Latham, Susie, and Linda Briskman. 2015. Anti-Muslim Sentiment Reaches Fever Pitch as Ministers Channel Their Inner Howard. Crikey, June 3. Available online: https:/ / www.crikey.com.au/2015/06/03/anti-muslimsentiment-reaches-fever-pitch-as-ministers-channel-their-inner-howard/ (accessed on 20 August 2018).

McCulloch, Jude, and Dean Wilson. 2015. Pre-Crime: Pre-Emption, Precaution and the Future. London: Routledge. 
Monaghan, Jeffrey. 2014. Security Traps and Discourses of Radicalization: Examining Surveillance Practices Targeting Muslims in Canada. Surveillance and Society 12: 485-501. [CrossRef]

Nolan, David, Karen Farquharson, Violeta Politoff, and Timothy Marjoribanks. 2011. Mediated Multiculturalism: Newspaper Representation of Sudanese Migrants in Australia. Journal of Intercultural Studies 32: 655-71. [CrossRef]

Oboler, Andre. 2016. The normalisation of Islamophobia through social media: Facebook. In Islamophobia in Cyberspace: Hate Crimes Go Viral. Edited by Imran Arwan. Abingdon: Routledge, pp. 41-61.

Offord, Baden, Erika Kerruish, Rob Garbutt, Adele Wessell, and Kirsten Pavlovic. 2014. Inside Australian Culture: Legacies of Enlightenment Values. London: Anthem Press.

Olding, Rachel. 2015. Prayer Group Audit at NSW Schools Reveals Guidelines Not Followed. Sydney Morning Herald, September 2. Available online: https:/ /www.smh.com.au/national/nsw / prayer-group-audit-atnsw-schools-reveals-guidelines-not-followed-20150902-gjdht1.html (accessed on 29 August 2018).

Overington, Caroline. 2018. Modest Fashion in Australia: DFAT's Message is Plain Wrong. The Australian, January 29.

Poynting, Scott, and Linda Briskman. 2017. Black Flags, Plastic Swords and Other Weapons of Mass Disruption in Australia. In Islamophobia. Edited by Narzanin Massoumi, Tom Mills, Hilary Aked and David Miller. London: Pluto Press.

Poynting, Scott, and Victoria Mason. 2007. The Resistible Rise of Islamophobia: Anti-Muslim Racism in the UK and Australia before 11 September 2001. Journal of Sociology 43: 61-86. [CrossRef]

Poynting, Scott, and Greg Noble. 2004. Living with Racism: The Experience and Reporting by Arab and Muslim Australians of Discrimination, Abuse and Violence Since 11 September 2001. Report to the Human Rights and Equal Opportunity Commission. April. Available online: http://www.hreoc.gov.au/racial_discrimination/ isma/research/index.html (accessed on 9 September 2018).

Poynting, Scott, and Barbara Perry. 2007. Climates of Hate: Media and State Inspired Victimisation of Muslims in Canada and Australia since 9/11. Current Issues in Criminal Justice 19: 151-71.

Poynting, Scott, Greg Noble, Paul Tabar, and Jock Collins. 2004. Bin Laden in the Suburbs: Criminalising the Arab Other. Sydney: Institute of Criminology.

Prevent Watch. 2018. The School Trip Case. Prevent Watch, April 12. Available online: https://www.preventwatch. org/the-school-trip-case/ (accessed on 9 September 2018).

Ramsay Centre. 2018. Former Prime Ministers Launch the Ramsay Centre for Western Civilisation. Ramsay Centre, January 8. Available online: http:/ / www.ramsayhealth.com/News/General-News/Former-PrimeMinisters-launch-Ramsay-Centre-for-Western-Civilisation (accessed on 2 August 2018).

Silmalis, Linda. 2017. Government to review deradicalisation program in wake of Punchbowl Boys saga. Sunday Telegraph, March 12. Available online: https://www.dailytelegraph.com.au/news/ nsw / government-to-review-deradicalisation-program-in-wake-of-punchbowl-boys-saga/news-story/ d864509a75ddd6dfb8f37448779ecc72 (accessed on 10 September 2018).

Smith, Alexandra. 2017. Punchbowl Boys' principal Chris Griffiths not given explanation for removal, court documents say. Sydney Morning Herald, April 17. Available online: https: / / www.smh.com.au/education/punchbowl-boys-principal-chris-griffiths-not-given-explanationfor-removal-court-documents-say-20170407-gvfqfz.html (accessed on 10 September 2018).

Soutphommasane, Tim. 2018. Confronting the Return of Race Politics. Lecture to the Whitlam Institute, Western Sydney Universit. August 6. Available online: https://www.humanrights.gov.au/news/speeches/ confronting-return-race-politics (accessed on 3 September 2018).

Spivak, Gayatri Chakravorty. 1988. Can the Subaltern Speak? Die Philosophin 14: 42-48.

Taylor, Lenore. 2011. Morrison sees votes in anti-Muslim strategy. Sydney Morning Herald, February 17. Available online: https://www.smh.com.au/national/morrison-sees-votes-in-anti-muslim-strategy20110216-1awmo.html\#ixzz2M9T7d6Og (accessed on 10 September 2018).

The Australian. 2015. Reflection on a Muslim Community under Siege. The Australian, May 23. Available online: https: / / www.theaustralian.com.au/opinion/editorials/reflections-on-a-muslim-community-undersiege/news-story/d5b71920f459ee5ecd73bbba3d3ae004 (accessed on 28 August 2018).

The Saturday Paper. 2018. Hypocrite to Child's Care. The Saturday Paper, March 2, p. 14. 
The West Australian. 2018. Suspicious Blaze at Al-Taqwa Masjid Mosque Sparks Arson Squad Investigation in Mirrabooka. The West Australian, August 26. Available online: https://thewest.com.au/news/crime/suspiciousblaze-at-al-taqwa-masjid-mosque-sparks-arson-squad-investigation-in-mirrabooka-ng-b88940756z (accessed on 30 August 2018).

Tudge, Alan. 2018. Maintaining Social Cohesion in a Time of Large, Diverse Immigration. Speech at the Australia-UK Leadership Forum. London. July 19. Available online: https://minister.homeaffairs.gov.au/ alantudge/Pages/maintaining-social-cohesion-in-a-time-of-large-diverse-immigration.aspx (accessed on 13 August 2018).

Urban, Rebecca. 2018. Sydney Uni Hit by Backlash While Looking to the West. The Australian, June 9. Available online: https:/ / www.theaustralian.com.au/higher-education/sydney-uni-hit-by-backlash-while-lookingto-the-west/news-story/7b097fa8960c271c0609ea62570c6206 (accessed on 1 September 2018).

Vollmer, Tim, and Nathan Klein. 2010. Burqa-clad Mum Carnita Matthews Jailed for Six Months. Daily Telegraph, November 19. Available online: https://www.dailytelegraph.com.au/news/ nsw /it-wasnt-me-in-that-burqa-says-accused/news-story/f92a09d50934c73ca64bbcc32c03fbd4?sv= 3749fc1c6e164cd0711c67ecb3f4fa33 (accessed on 28 August 2018).

Williams, George. 2011. A Decade of Australian Anti-Terror Laws. Melbourne University Law Review 35: $1136-76$. Wilson, Jason. 2018. Why is the Australian Media Promoting White Nationalist Ideas? The Guardian, August 8. Available online: https:/ / www.theguardian.com/australia-news/commentisfree/2018/aug/08/why-isthe-australian-media-promoting-white-nationalist-ideas (accessed on 13 August 2018).

(C) 2018 by the authors. Licensee MDPI, Basel, Switzerland. This article is an open access article distributed under the terms and conditions of the Creative Commons Attribution (CC BY) license (http:/ / creativecommons.org/licenses/by/4.0/). 